\title{
Pengaruh Pemahaman Knowledge Sharing terhadap Prestasi Mahasiswa yang Melaksanakan Praktek Pengalaman Lapangan (Studi pada Mahasiswa STKIP Nasional Padang Pariaman)
}

\author{
Sumarni \\ Dosen STKIP Nasional Padang Pariaman
}

\begin{abstract}
Abstrak: Tujuan dari penelitian ini adalah untuk menganalisa pemahaman knowledge sharing terhadap prestasi mahasiswa yang melaksanakan praktek pengalaman lapangan. Penelitian ini menggunakan metode penelitian kuantitatif dengan rancangan penelitian yang digunakan adalah penelitian deskriptif. Populasi sebanyak 176 mahasiswa dengan menggunakan teknik sampling non probability sampling, sehingga sampel menjadi 64 mahasiswa dihitung dengan menggunakan rumus slovin. Teknik analisis data yang digunakan dalam penelitian ini adalah statistik deskriptif, uji asumsi klasik dan analisis regresi linier dengan bantuan program komputer versi 23. Hasil penelitian ini menggunakan uji t, dimana knowladge sharing (X) memiliki arah nilai positif yaitu 4,035 yang memilki nilai yang lebih besar dari t tabelnya sebesar 1.671 dengan nilai signifikansi sebesar $0,000<0,05$ yang artinya berpengaruh signifikan. Sehingga dapat disimpulkan bahwa pemahaman knowladge sharing (X) berpengaruh terhadap prestasi mahasiswa yang melaksanakan praktek pengalaman lapangan.
\end{abstract}

Kata kunci: Pemahaman Knowladge Sharing, Prestasi

\begin{abstract}
The purpose of this study is to analyze the understanding of knowledge sharing on the achievements of students who carry out field experience. This research uses quantitative research methods with the research design used is descriptive research. The population was 176 students using a non probability sampling technique, so the sample of 64 students was calculated using the Slovin formula. Data analysis techniques used in this study were descriptive statistics, classic assumption tests and linear regression analysis with the help of a computer program version 23. The results of this study use the t test, where knowladge sharing $(X)$ has a positive value direction of 4.035 which has a value greater than t table of 1,671 with a significance value of $0,000<0.05$ which means that it has a significant effect. So it can be concluded that the understanding of knowledge sharing (X) affects the achievement of students who carry out field experience.
\end{abstract}

Keywords: Understanding Knowledge Sharing, Achievement

\section{PENDAHULUAN}

Globalisasi merupakan suatu fenomena perubahan sosial yang tidak dapat terelakan lagi keberadaannya. Pesatnya perkembangan globalisasi ini ditandai dengan kemajuan ilmu pengetahuan serta teknologi yang semakin canggih dalam segala aspek kehidupan manusia. Globalisasi ini selain memberikan dampak pisitf, tetapi juga akan berdampak negatif jika manusia tidak bijak dalam memanfaatkannya. Dengan adanya globalisasi pada saat ini membuat persaingan sumber daya manusia semakin ketat. Salah satu upaya yang dapat dilakukan manusia untuk bersaing di masa depan adalah dengan menempuh pendidikan setinggi-tingginya. Jenjang pendidikan tinggi adalah suatu wadah untuk menciptakan sumberdaya manusia yang berkualitas dan tepat guna sesuai dengan kebutuhan zaman. Seperti tujuan dari Sistem Pendidikan Nasional berdasarkan UU No 20 Tahun 2003 yaitu:

"Pendidikan adalah usaha sadar dan terencana untuk mewujudkan suasana belajar dan proses pembelajaran agar peserta didik aktif mengembangkan potensi dirinya untuk memiliki kekuatan spiritual keagamaan, pengendalian diri, kepribadian, kecerdasan, akhlak mulia, serta keterampilan yang diperlukan dirinya".

Pendidikan merupakan proses perubahan sikap dan tingkah laku seseorang dalam mendewasakan diri melalui upaya pembelajaran dan pelatihan, agar mewujudkan manusia yang tidak hanya pandai dalam hal akademik namun juga menjadi manusia yang berkarakter, pendidikan dapat ditempuh baik melalui pendidikan formal disekolah maupun pendidikan non formal diluar sekolah. Pendidikan formal yang merupakan salah satu solusi utama untuk membentuk sumber daya manusia yang berkualitas, karena dengan pendidikan memungkinkan untuk mengembangkan kemampuan akademis maupun keterampilan lain yang dimiliki sehingga dapat digunakan secara efektif dan efisien untuk bekal kehidupannya. Dalam lingkungan pendidikan formal ini setiap individu akan mendapatkan pendidikan yang lebih luas di banding dengan pendidikan non formal.

Pendidikan formal merupakan pendidikan di sekolah yang di peroleh secara teratur, sistematis, bertingkat atau berjenjang, dan dengan mengikuti syarat-syarat yang jelas. Sebagai lembaga pendidikan formal, sekolah yang lahir dan berkembang secara efektif dan efisien dari dan oleh serta untuk masyarakat, merupakan perangkat yang 
berkewajiban memberikan pelayanan kepada generasi muda dalam mendidik warga negara. Perguruan tinggi adalah tahap akhir opsional pada pendidikan formal. Perguruan tinggi bisa berbentuk Universitas, Akademi, Sekolah Tinggi, Collage, dan Institut.

STKIP Nasional Padang Pariaman merupakan salah satu bentuk dari Perguruan tinggi yang akan menciptakan sumber daya manusia seperti calon guru yang berkualitas. Untuk menghasilkan calon guru yang berkualitas para mahasiswa terlebih dahulu didik dan dilatih melalui mata kuliah PPL (Praktek Pengalaamn Lapangan) yang dikirimkan ke sekolah-kesekolah formal menjadi seorang guru praktek.

Sebagaimana diketahui bahwa kegiatan program PPL lebih banyak memberikan kesiapan bagi calon guru untuk "berdiri" di depan kelas dan kegiatan lainnya untuk peningkatan keterampilan dalam bidang administrasi dan manajemen sekolah. Padahal, keberhasilan pendidikan, profesionalisme guru dan calon guru, tidak cukup hanya ditentukan oleh "kebolehan" guru dalam mengelola pembelajaran di depan kelas dan keterampilan administrasi serta manajemen sekolah saja tetapi juga faktor lainnya sesuai dengan 4 kompetensi guru. Keterampilan dalam mengelola pelatihan guru bidang studi, pengalaman dalam penyelenggaraan berbagai lomba pendidikan, kemampuan untuk mengelola kegiatan ekstra kurikuler, membina dan mengkoordinasikan asosiasi guru bidang studi, dan menjalin hubungan dengan pihak terkait untuk keberhasilan siswa, semuanya merupakan komponen pendukung profesionalisme keguruan. Di samping itu, melakukan usaha preventif terhadap pengaruh narkoba bagi para siswa, menangani kenakalan siswa, mengatur manajemen dan administrasi pendidikan, serta banyak lagi lainnya, pada umumnya tidak/belum tertuang dalam program kegiatan PPL itu sendiri.

Dua faktor utama yang perlu mendapat perhatian dalam peningkatan kualitas calon guru lewat PPL tersebut adalah pemberdayaan dan pembudayaan. Faktor pemberdayaan mencakup peningkatan kemampuan dan pengelolaan sumber daya sehingga memiliki relevansi tinggi dengan manajemen dan administrasi yang tangguh. Sedangkan faktor pembudayaan meliputi kemauan, etos kerja, dan keberlanjutan (sustainability) program peningkatan kualitas calon guru.

Keterampilan dasar mengajar adalah keterampilan dalam hal: (1) memulai dan mengakhiri pembelajaran (2) menjelaskan sesuatu (3) reinforcement (4) menggunakan media (5) menyusun skenario pembelajaran (6) mengadakan variasi pembelajaran (7) membimbing diskusi (8) mengelola kelas (9) memotivasi bertanya, dan (10) mengevaluasi secara bertahap dan terpisah. Sedangkan untuk keterampilan dasar mengajar terpadu adalah beberapa jenis keterampilan yang dipadukan dan dilakukan dalam waktu pembelajaran tertentu. Di samping itu, beberapa kecakapan hidup dalam pembelajaran juga dilatihkan seperti: kecakapan mengenal diri, kecakapan berpikir, kecakapan sosial, kecakapan akademik, dan kecakapan voksional.

Untuk memilki keterampilan dasar mengajar tersebut diperlukan pemahaman knowladge sharing. Dimana, Knowledge Sharing dapat dipahami sebagai perilaku dimana seseorang secara sukarela menyediakan akses terhadap orang lain mengenai knowledge dan pengalamannya. Hansen dan Avital (dalam Hilmi A., et al. 2009). Pemahaman knowladge sharing perlu dimilki mahasiswa yang menjalankan PPL agar keterampilan dasar mengajar bisa dijalankan dengan baik. Apabila mahasiswa PPL memilki pemahaman yang baik, maka akan dapat memberikan prestasi bagi mereka dalam mengajar yaitu berhasilnya mereka dalam mentransfer ilmu pengetahuan kepada siswa dengan ditandai hasil belajar yang bagus. Demikian pula sebaliknya, apabila mahasiswa PPL memilki pemahaman yang kurang baik, maka akan dapat memberikan prestasi jelek bagi mereka dalam mengajar yaitu tidak berhassilnya mereka dalam mentransfer ilmu pengetahuan kepada siswa dengan ditandai hasil belajar yang jelek. Adapun tujuan dari penuisan ini adalah untuk menganalisa pemahaman knowledge sharing terhadap prestasi mahasiswa yang melaksanakan praktek pengalaman lapangan.

\section{Landasan Teori}

\section{Praktek Pengalaman Lapangan}

Mata kuliah PPL mempunyai sasaran masyarakat sekolah, baik dalam kegiatan yang berkaitan dengan pembelajaran maupun kegiatan yang mendukung pembelajaran. PPL diharapkan dapat memberikan pengalaman belajar bagi mahasiswa, terutama dalam pengalaman mengajar, memperluas wawasan, melatih dan mengembangkan kompetisi yang diperlukan dalam bidangnya, meningkatkan keterampilan, kemandirian, tanggung jawab, dan kemampuan dalam memecahkan masalah.

Sebelum melakukan kegiatan PPL, mahasiswa diberikan pembekalan PPL yang disebut micro teaching atau pengajaran mikro. Menurut J. Coover dan D.W Allen, (dalam Hamalik, 2009) mengemukakan tentang pengajaran mikro (micro teaching) adalah studi tentang suatu situasi pengajaran yang dilaksanakan dalam waktu dan jumlah siswa tertentu, yakni empat atau sampai dua puluh menit dengan jumlah siswa sebanyak tiga sampai sepuluh orang. Sedangkan menurut Hamalik (2009) pengajaran mikro adalah pengajaran di mana menempatkan guru dalam suatu lingkungan kelas simulasi, dimana guru mengajar satu konsep atau satu keterampilan saja, menggunakan satu keterampilan mengajar dan siswa dalam jumlah kecil serta dalam waktu yang pendek. 
Selanjutnya menurut Sabrani (2007) tujuan khusus pengajaran mikro adalah setelah calon guru mengalami latihan ini maka diharapkan: 1) Dapat menganalisis tingkah laku mengajar kawan-kawannya dan diri sendiri. 2) Dapat melaksanakan keterampilan khusus dalam mengajar. 3) Dapat mempraktekan berbagai teknik mengajar dengan benar dan tepat. 4) Dapat mengwujudkan situasi belajar mengajar yang efektif, produktif dan efisien. 5) Dapat bersikap profesional keguruan. Lebih lanjut Sabrani (2007), mengemukakan tujuan operasional dari micro teaching yaitu:

1) Dapat mengembangkan kemampuan diri untuk mawas diri dan menilai orang lain.

2) Memungkinkan adanya perbaikan dalam waktu singkat.

3) Menanamkan rasa percaya pada diri dan sifat terbuka dari kritik orang lain.

4) Mengembangkan sikap kritis mahasiswa.

5) Menanamkan kesadaran akan nilai keterampilan mengajar dan komponen-komponennya.

6) Menyiapkan bekal mahasiswa dalam menghadapi praktik keguruan dan memecahkan kesulitan dalam mengajar.

7) Mengenal kelemahan-kelemahan dan kekeliruan-kekeliruan dalam penampilan, keterampilan mengajar siswa serta tahu penampilan-penampilan yang baik.

8) Dengan menggunakan Video Tap Recorder maka: a) Memberikan kesempatan pada mahasiswa untuk melihat dan mendengar dirinya sendiri seperti, murid-murid atau teman-teman waktu ia mengajar. b) memberi kesempatan untuk mengikuti kembali kritik dan diskusi cara ia mengajar yang berulangkali. c) Memungkinkan untuk melihat model cara mengajar. d) Memungkinkan banyak orang yang dapat mengikuti proses mengajar, dan tidak tertentu waktunya. e) Memberi medan untuk mencobakan sistem atau metode baru untuk diteliti sebelum dikembangkan. f) memberi kesempatan pendekatan analisis mengenal keterampilan dan strategi mengajar.

Kegiatan PPL dilakukan untuk dapat memberikan pengalaman belajar bagi mahasiswa terutama dalam hal pengalaman mengajar, memperluas wawasan, melatih dan mengembangkan kompetensi yang diperlukan dalam bidangnya, meningkatkan keterampilan, kemandirian, tanggung jawab, dan kemampuan dalam memecahkan masalah. Kegiatan ini mempunyai sasaran masyarakat sekolah, baik dalam kegiatan yang terkait dengan pembelajaran maupun kegiatan yang mendukung berlangsungnya pembelajaran.

Praktik Pengalaman Lapangan (PPL) adalah serangkaian kegiatan yang diprogramkan bagi mahasiswa LPTK, yang meliputi baik latihan mengajar di dalam kelas (yang bersifat akademik) maupun latihan mengajar di luar kelas (yang bersifat non akademik). Kegiatan ini merupakan ajang untuk membentuk dan membina kompetensi-kompetensi profesional yang diisyaratkan oleh pekerja guru atau tenaga kependidikan yang lain. Persepsi mahasiwa terhadap PPL adalah dengan PPL dapat memberikan pengalaman bagi mereka baik dalam bidang pembelajaran dan manajerial di sekolah maupun lembaga dalam rangka melatih dan mengembangkan kompetensi menjadi guru salah satunya dibentuk melalui program PPL.

\section{Pemahaman Knowledge Management}

Pemahaman adalah suatu proses, cara memahami, cara mempelajari sesuatu dengan baik supaya paham dan mempunyai pengetahuan. Arikunto (2009) menyatakan bahwa pemahaman (Comprehension) adalah bagaimana seseorang mempertahankan, membedakan, menduga (estimates), menerangkan, memperluas, menyimpulkan, menggeneralisasikan, memberikan contoh, menuliskan kembali, dan memperkirakan. Menurut Anas (2012) Pemahaman adalah kemampuan seseorang untuk mengerti atau memahami sesuatu setelah sesuatu itu diketahui atau diingat. Dengan kata lain memahami adalah mengetahui tentang sesuatu dan dapat melihatnya dari berbagai segi. Seorang siswa dikatakan memahami sesuatu apabila ia dapat memberikan penjelasan atau memberi uraian lebih rinci tentang hal itu dengan menggunakan kata-katanya sendiri. Sedangkan menurut Winkel dan Mukhtar (Sudaryono, 2012), pemahaman adalah kemampuan seseorang untuk menangkap makna dan arti dari bahan yang dipelajari, yang dinyatakan dengan menguraikan isi pokok dari suatu bacaan atau mengubah data yang disajikan dalam bentuk tertentu ke bentuk yang lain.

Proses belajar dan mengajar yang terjadi di kelas merupakan proses komunikasi antara guru dan anak didik. Dan, komunikasi yang lancar ditengarai mempunyai andil yang cukup besar dalam upaya peningkatan kualitas pembelajaran yang dilaksanakan oleh guru. Sebagai sebuah proses transfer pengetahuan (transfer of knowledge), proses pembelajaran pada kenyataannya tidak hanya tergantung pada penguasaan materi pembelajaran oleh sang guru. Guru yang menguasai materi pembelajaran secara tuntas tidak selalu menjadi tanggungan bahwa proses pembelajarannya akan berhasil.

Berbagi pengetahuan adalah kegiatan bekerjasama yang dilakukan untuk meningkatkan pengetahuan dan keterampilan agar tercapai tujuan individu serta organisasi. Berbagi pengetahuanmerupakan interaksi sosial yang melibatkan pengetahuan, pengalaman dan keterampilan antara karyawan untuk meningkatkan kompetensi yang dimiliki (Pramono dan Susanty, 2015). Menurut Triana dkk (2016) berbagi pengetahuan merupakan proses yang sistematis dalam penyampaian pesan antar individu maupun organisasi melalui media yang beragam. Setiap individu 
berhak menentukan media apa yang akan mereka pakai untuk melakukan berbagi pengetahuan, yang terpenting adalah penerima pesan mampu memahami apa yang telah disampaikan.

Subagyo (dalam Wahyuni dan Kistyanto, 2013) knowledge sharing merupakan salah satu metode atau salah satu langkah dalam manajemen pengetahuan yang digunakan untuk memberikan kesempatan kepada anggota suatu kelompok, organisasi, instansi atau perusahaan untuk berbagi ilmu pengetahuan, teknik, pengalaman dan ide yang mereka miliki kepada anggota lainnya. Sajeva (2014) mendefinisikan knowledge sharing sebagai, "transfer, dissemination, and exchange of knowledge, experience, skills, and valuable information from one individual to other members within anorganization."

Knowledge sharing merupakan proses yang sistematis dalam mengirimkan, mendistribusikan, dan mendiseminasikan pengetahuan dan konteks multidimensi dari seorang atau organisasi kepada orang atau organisasi lain yang membutuhkan melalui metode dan media yang variatif (Lumantobing, 2011). Raskov (2007) memberi pengertian knowledge sharing terjadi antar individu dalam suatu komunitas, dimana individu berinteraksi dan berbagi pengetahuan dengan individu lainya melalui ruang maya atau tatap muka, Community of Practice (CoP), group, forum dan sejenisnya. Sehingga unit analisis dalam knowledge sharing adalah individu. Sedangkan Sanchez dkk. (2013) menyatakan bahwa knowledge sharing adalah bagian utama dari knowledge management.

Berbagi pengetahuan (knowledge sharing) merupakan suatu proses di mana para individu saling mempertukarkan pengetahuan mereka dari tacit knowledge menjadi explicit knowledge (Gitanauli, 2010). Untuk menjadi suatu "pengetahuan" diperlukan suatu proses penciptaan yang cukup cermat. Proses penciptaan pengetahuan dapat dimulai dari mengumpulkan dan merekam data, mengumpulkan dan mengelola informasi, hingga mengolah informasi menjadi pengetahuan.

Menurut Carrillo et al., (dalam Noviyanti,2015) Knowledge sharing dibagi menjadi dua jenis yaitu tacit knowledge dan explicit knowledge. Berdasarkan pengertianya, maka tacit knowledge dikategorikan sebagai personal knowledge atau dengan kata lain pengetahuan yang diperoleh dari individu atau perorangan. Pengalaman yang telah diperoleh tiap individu tentunya berbeda-beda berdasarkan situasi dan kondisi yang tidak dapat diprediksi. Sedangkan explicit knowledge adalah knowledge yang dapat atau sudah terkodifikasi dalam bentuk dokumen atau bentuk berwujud lainya sehingga dapat dengan mudah ditransfer dan di distribusikan dengan menggunakan berbagai media. Explicit knowledge bersifat formal dan sistematis yang mudah untuk dikomonikasikan dan dibagi. Penerapan explicit knowledge ini lebih mudah karena pengetahuan yang diperoleh dalam bentuk tulisan atau pernyataan yang didokumentasikan, sehungga setiap individu dapat mempelajarinya secara independent. Menurut Setiaso (2006), secara umum ada lima jenis kegiatan knowledge sharing yaitu:

1. Di dalam satu kelompok untuk pekerjaan rutin yang serupa dan terus menerus,

2. Antar dua atau lebih kelompok yang berbeda tetapi melakukan pekerjaan yang hampir sama,

3. Antar dua atau lebih kelompok, tetapi yang dibagi bersama adalah pengetahuan tentang pekerjaan non-rutin,

4. Antar organisasi dalam rangka kelangsungan hidup bersama,

5. Dari luar kelompok, ketika menghadapi persoalan yang belum pernah mereka jumpai.

Knowledge sharing memiliki beberapa manfaat, menurut Andika (2015) menyampaikan manfaat dari Knowledge Sharing antara lain: a) mendorong penyebaran pembelajaran individu ke seluruh organisasi, b) memfasilitasi pengembangan kompetensi, c) berpengaruh positif terhadap kinerja anggota organisasi, d) berpengaruh positif terhadap perilaku kerja inovatif, e) berpengaruh positif terhadap kapabilitas inovasi organisasi .

\section{Prestasi Mahasiswa Praktek Pengalaman Lapangan}

Prestasi pada hakikatnya merupakan hasil dari suatu tindakan yang dilakukan. Prestasi bisa juga disebut sebagai hasil belajar, prestasi belajar, dan prestasi akademik. Prestasi atau hasil belajar (achievement) merupakan realisasi atau pemekaran dari kecakapan-kecakapan potensial atau kapasitas yang dimiliki soseorang (Sukmadinatan, 2011). Selanjutnya Fatimah dan Fasikhah (2013) mendefinisikan Prestasi akademik adalah hasil belajar dalam bidang akademis yang merefleksikan kemampuan dan kinerja mahasiswa terhadap materi pelajaran yang bersifat multidimensi yang mencakup aspek kognitif, afektif dan psikomotor, yang diberikan oleh pendidik kepada peserta didik yang lazimnya ditunjukkan dengan nilai.

Menurut Bloom (Hartaji, 2008), "prestasi akademik atau prestasi belajar adalah proses yang dialami peserta didik (siswa/mahasiswa) dan menghasilkan perubahan dalam bidang pengetahuan, pemahaman, penerapan, daya analisis, sintesis dan evaluasi". Sedangkan Syah (2010) menyatakan bahwa Prestasi belajar merupakan tingkat keberhasilan siswa dalam mencapai tujuan yang telah ditetapkan dalam sebuah program".

Lebih lanjut dijelaskan bahwa hampir sebagian besar dari perilaku yang diperlihatkan seseorang merupakan hasil belajar. Perilaku ini dapat berupa perilaku dalam bentuk penguasaan pengetahuan, ketampilan berpikir maupun keterampilan motorik. Tingkat pen0guasaan hasil belajar biasanya dilambangkan angka $0-10$ pada pendidikan dasar dan menengah serta huruf A, B, C, D pada pendidikan tinggi. 


\section{METODE}

Penelitian ini menggunakan metode penelitian kuantitatif dengan rancangan penelitian yang digunakan adalah penelitian deskriptif. Tujuan deskriptif adalah untuk menggambarkan berbagai karateristik dari fenomena yang diamati, misalnya dalam penelitian ini mengenai pemahaman knowledge sharing, dan prestasi mahasiswa yang melaksanakan praktek pengalaman lapangan. Berdasarkan tujuan deskriptif tersebut dapat digambarkan model penelitian empirik pada gambar 1 dibawah ini:

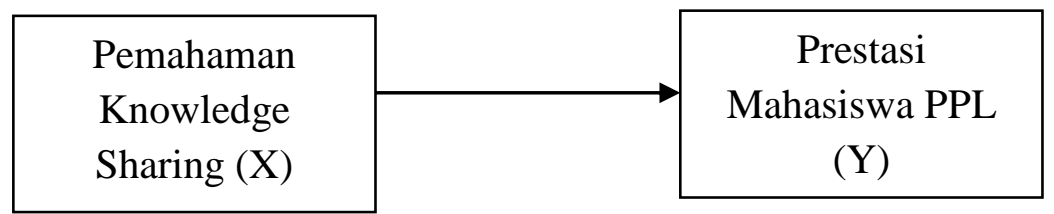

Gambar 1. Model Penelitian

Populasi dalam penelitian ini adalah seluruh seluruh mahasiswa yang melaksanakan praktek pengalaman lapangan dari berbagai program studi yang ada di STKIP Nasional Padang Pariaman sebanyak 176 mahasiswa. Mengingat unit analisis bersifat heterogen yang dilihat dari sisi bidang keilmuan masing-masing program studi maka tehnik penarikan sampel dilakukan secara non probability. Sampel dalam penelitian ini ditentukan dengan menggunakan rumus Slovin (Sani, 2013) sebagai berikut:

$n=\frac{N}{N(e)^{2}+1}$

Keterangan:

n : banyak sampel

$\mathrm{N} \quad$ : banyak populasi

e $\quad$ : persentase kesalahanyang diinginkan atau ditolelir dengan populasi dan presisi $10 \%$

Jumlah sampel dalam penelitian ini bila diketahui populasi $(\mathrm{N})=176$ mahasiswa dan $\mathrm{e}=10 \%$, maka dapat diketahui jumlah sampel sebagai berikut:

$n=\frac{176}{176(0,1)^{2}+1}$

$n=\frac{176}{176(0,01)+1}$

$n=\frac{176}{2,76}=63,7$

$n=63.7=64$

Dari rumus Slovin tersebut jumlah sampel penelitian ini sebanyak 64 mahasiswa. Alat ukur yang digunakan dengan melakukan penyebaran kuisioner pada para mahasiswa yang menjadi sampel dengan rentang nilai skala likert. Teknik analisis data yang digunakan dalam penelitian ini adalah analisis deskriptif, uji asumsi klasik dan analisis regresi linier sederhana $(\mathbf{Y}=\boldsymbol{\alpha}+\boldsymbol{\beta} \mathbf{X}+\mathbf{e})$ untuk mengetahui pengaruh pemahaman knowledge management terhadap kinerja mahasiswa PPL dengan bantuan program komputer SPSS versi 23 (Gozali, 2011).

\section{HASIL DAN PEMBAHASAN}

Untuk menjawab tujuan dari penelitian ini, telah dilakukan uji pengaruh knowladge management terhadap prestasi mahasiswa yang melaksanakan Praktek Pengalaman Lapangan. Hasil Penelitian ini dihitung menggunakan teknik analisis data regresi linier sederhana. Namun sebelum melangkah pada analisis tersebut, terlebih dahulu harus mengetahui perhitungan data deskriptifnya untuk mengetahui nilai mean, standar deviasi, nilai minimum dan maksimum dari data yang telah diperoleh pada saat melakukan penelitian. Berikut dapat diketahui pada tabel 1 tentang analisis deskriptif dari penelitian ini:

Tabel 1. Analisis Deskriptif Descriptive Statistics

\begin{tabular}{|c|c|c|c|c|c|}
\hline & N & Mean & Std. Deviation & Minimum & Maximum \\
\hline KnowladgeSharing & 64 & 71,05 & 5,565 & 60 & 80 \\
Prestasi & 64 & 72,27 & 5,118 & 66 & 85 \\
\hline
\end{tabular}


Dari table di atas dapat diketahui ilustrasi data tentang knowladge sharing (X) dan prestasi mahasiswa (Y). Dimana, untuk variabel knowladge sharing (X) memiliki nilai rata-rata yang sebesar 71,05, standar deviasi sebesar 5,565, nilai minimum 60 dan nilai maksimum sebesar 80. Lebih lanjut untuk variabel prestasi (Y) memilki nilai ratarata sebesar 72,27, standar deviasi sebesar 5,118, nilai minimum 66 dan nilai maksimum sebesar 85 . Data-data tersebut dapat disimpulkan bahwa data variable knowladge sharing $(\mathrm{X})$ sebagai variabel bebas dan prestasi mahasiswa (Y) sebagai variabel terikat menunjukkan hasil yang baik, hal tersebut dikarenakan standar deviasi yang mencerminkan penyimpangan dari data variabel-variabel tersebut lebih kecil dari rata-ratanya.

Sebelum melakukan uji hipotesis dengan menggunakan analisis regresi linier sederhana yang dapat dikatakan menghasilkan estimator yang baik apabila memenuhi asumsi-asumsi yang sangat berpengaruh pada pola perubahan variabel terikat, diantaranya melakukan uji normalitas, dan homogenitas sebagai uji asumsi klasik. Adapun hasil dari perhitungan uji normalitas dapat dilihat pada tabel 2 berikut:

Tabel 2. Uji Normalitas

One-Sample Kolmogorov-Smirnov Test

\begin{tabular}{|ll|r|r|}
\hline & & KnowladgeSharing & Prestasi \\
\hline N & & 64 & 64 \\
Normal Parameters & Mean & 71,05 & 72,27 \\
& Std. Deviation & 5,565 & 5,118 \\
Most Extreme Differences & Absolute &, 121 &, 126 \\
& Positive &, 096 &, 126 \\
& Negative &,- 121 &,- 110 \\
Test Statistic & &, 121 &, 126 \\
Asymp. Sig. (2-tailed) & &, $222^{\mathrm{c}}$ &, $113^{\mathrm{c}}$ \\
\hline
\end{tabular}

a. Test distribution is Normal.

b. Calculated from data.

c. Lilliefors Significance Correction.

Uji normalitas menggunakan uji statistik non parametrik Kolmogorov Smirnov (K-S). Uji K-S (Singgih, 2010) dilakukan dengan syarat:

- Jika nilai Asymp. Sig. (2 - tailed) lebih besar dari 0,05 data berdistribusi normal

- Jika nilai Asymp. Sig. (2 - tailed) lebih kecil dari 0,05 data tidak berdistribusi normal

Tabel di atas menunjukan hasil uji normalitas dengan menggunakan Uji One-Sample Kolmogorov-Smirnov Test dengan besaran masing-masing variabel rasio likuiditas menunjukan nilai asymp sig variable knowladge sharing (X) sebesar 0,222 lebih besar dari 0,05, dan variabel prestasi mahasiswa (Y) sebesar 0,113 lebih besar dari 0,05 maka data berdistribusi normal. Sedangkan uji homogenitas data dapat dilihat pada tabel 3 berikut:

Tabel 3. Uji Homogenitas

Test of Homogeneity of Variances

KnowladgeSharing

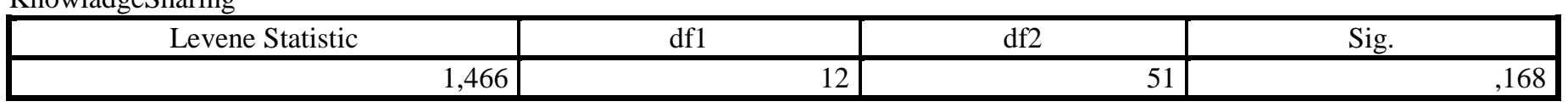

Uji homogenitas dilakukan untuk menguji apakah variasi kelompok populasi homogeny atau tidak, uji homogeny menurut Singgih (2010) dilakukan dengan menggunakan uji Levene dengan syarat:

- Jika nilai signifikansi. > 0,05 (taraf kepercayaan $95 \%$ ), data yang digunakan adalah homogen.

- Jika nilai signifikansi. <0,05 (taraf kepercayaan 95\%), data yang digunakan adalah tidak homogen.

Tabel di atas menunjukan hasil uji homogenitas dengan menggunakan Uji Levene Test dengan nilai asymp sig sebesar 0,168 ;ebih besar dari 0,05, maka data tersebut dapat dikatakan homogen. Apabila data telah memenuhi syarat uji asumsi klasik, maka dapat dilakukan uji hipotesis dengan menggunakan teknik analisis regresi linier sederhana yang dapaat dilihat pada tabel 4 berikut ini: 
Tabel 4. Uji Homogenitas

\begin{tabular}{|ll|r|r|r|r|r|}
\hline \multirow{2}{*}{ Model } & \multicolumn{2}{|c|}{$\begin{array}{c}\text { Unstandardized } \\
\text { Coefficients }\end{array}$} & $\begin{array}{c}\text { Standardized } \\
\text { Coefficients }\end{array}$ & & \multirow{2}{*}{} \\
\cline { 2 - 5 } & \multicolumn{1}{c|}{$\mathrm{B}$} & Std. Error & \multicolumn{1}{c|}{ Beta } & \multicolumn{1}{c|}{ Sig. } \\
\hline 1 & (Constant) & 20,508 & 5,082 & & 4,035 &, 000 \\
& $\begin{array}{l}\text { Knowladge } \\
\text { Sharing }\end{array}$ &, 729 &, 071 &, 792 & 10,215 &, 000 \\
\hline
\end{tabular}

Analisis regresi linier sederhana yang digunakan dalam penelitian ini dapat dirumuskan $\mathbf{Y}=\boldsymbol{\alpha}+\boldsymbol{\beta} \mathbf{X}+\mathbf{e}$. Output analisis regresi linier sederhana pada tabel 4 diperoleh persamaan $Y=20,508+0,729 \mathrm{X}$. Dari model regresi tersebut dapat dijelaskan makna tentang model analisis regresi linear sederhana sebagai berikut:

1. Nilai konstanta sebesar 20,508 artinya apabila variabel independen yaitu knowladge sharing (X) bernilai nol (0), maka variabel dependen (Y) yaitu prestasi mahasiswa akan bernilai tetap sebesar 20,508.

2. Koefisien regresi variabel knowladge sharing (X) bernilai positif sebesar 0,729X, mengalami peningkatan sebesar 1 (satu) satuan sedangkan variabel lainnya dianggap konstan, maka variabel Y yaitu prestasi mahasiswa akan mengalami peningkatan sebesar 0,729 atau $72,9 \%$ untuk variabel variable knowladge sharing (X) (kalau positif, Variabel X Meningkat dan Variabel Y meningkat)

Perhitungan selanjutnya untuk menjawab hipotesa dari tujuan penelitian terdapat pengaruh atau tidaknya variabel knowladge sharing $(\mathrm{X})$ terhadap prestasi mahasiswa digunakan perhitungan yang dilihat dari besarnya uji $\mathrm{t}$ pada tabel 4 di atas. Hasil penelitian ini menunjukkan bahwa variabel knowladge sharing (X) berpengaruh terhadap prestasi mahasiswa (Y). Hal ini bisa dilihat dari hasil uji t yang diperoleh, dimana knowladge sharing (X) memiliki arah nilai positif yaitu 4,035 yang memilki nilai yang lebih besar dari t tabelnya sebesar 1.671 dengan nilai signifikansi sebesar 0,000 $<0,05$ yang artinya signifikan. Dengan demikian, knowladge sharing (X) berpengaruh terhadap prestasi mahasiswa $(\mathrm{Y})$.

Merujuk pada hasil dari hipotesis menunjukan bahwa ada pengaruh variabel knowladge sharing (X) terhadap prestasi mahasiswa, dimana variabel knowladge sharing $(\mathrm{X})$ dalam penelitian ini diukur dengan menggunakan 2 indikator diantaranya tacit knowledge dan explicit knowledge Temuan ini mengindikasikan bahwa variabel knowladge sharing $(\mathrm{X})$ mampu memprediksi variabel prestasi mahasiswa. Fakta tersebut menunjukkan bahwa prestasi mahasiswa dalam konteks penelitian ini diakibatkan oleh knowladge sharing (X). Artinya secara empirik khususnya pada mahasiswa STKIP Nasional Padang Pariaman yang melakukan Praktek Pengalaman Lapangan (PPL) prestasinya dipengaruhi oleh knowladge sharing (X). Hal tersebut dibuktikan bahwa hampir setiap tahunnya STKIP Nasional Padang Pariaman mengirimkan mahasiswanya untuk melaksanakan PPL tidak ada mahasiswa yang gagal dalam proses pelaksanaan PPL. Mereka sukses melatih diri mereka menjadi calon guru yang dibutuhkan oleh masyarakat yang ditunjukan dengan prestasi atau hasil nilai selama melakukan PPL semua mahasiswa menunjukan nilai yang terbaik atau dikategorikan lulus dengan menerapkan knowladge sharing dalam proses pembelajaran selama PPL. Hasil penelitian tersebut sejalan dengan penelitian yang dilakukan oleh Prasasti (2012) bahwa pembelajaran yang melakukan pemahaman Active Knowledge Sharing peserta didik melakukan kegiatan pembelajaran untuk tidak hanya menerima pelajaran saja akan tetapi proses menemukan materi pelajaran dengan cara berbagi pengetahuan dengan sesama teman. Melalui proses saling berbagi pengetahuan peserta didik dapat saling bertukar pengetahuan sehingga materi yang dipelajari akan tertanam kuat dalam memori siswa dan tidak mudah dilupakan. Hasil dari penelitian ini dapat diketahui bahwa adanya pengaruh pembelajaran Active Knowledge Sharing terhadap keterampilan proses sains dan juga terdapat pengaruhnya terhadap hasil belajar ranah kognitif dan afektif.

Penjelasan dari penelitian ini adalah bahwa pembelajaran Active Knowledge Sharing memberikan pengaruh yang baik bagi keberhasilan siswa dalam belajar. Tidak hanya dari segi pengetahuan kognitif saja peserta didik mendapatkan pengetahuan, melainkan dari sikap dan perilaku mereka dalam proses pembelajaran. Dengan demikian di dalam diri peserta didik telah terjadi belajar bermakna. Artinya peserta didik memeliki pengetahuan aspek kognitif, afektif dan psikomotorik. Sehingga penelitian ini sejalan dengan konsep teori konstruktivisme yang lebih menekankan perkembangan konsep dan pengertian yang mendalam.

\section{SIMPULAN}

Hasil perhitungan dan pembahasan yang telah dianalisis dalam penelitian ini dapat disimpulkan bahwa dari hasil uji t diperoleh hasil bahwa knowladge sharing (X) berpengaruh terhadap prestasi mahasiswa PPL. Adapun saran yang dapat diberikan kepada STKIP Nasional Padang Pariaman dan pihak lain yaitu : 1) Bagi mahasiswa STKIP Nasional Padang Pariaman diharapkan dapat terus meningkatkan efektivitas penerapan pemahaman knowladge sharing (X) agar dapat mengatasi hambatan-hambatan yang terdapat dalam aktivitas belajar pembelajaran saat melaksanakan PPL, 2) Bagi mahasiswa lain selain dari STKIP Nasional Padang Pariaman sebaiknya dapat 
Sumarni, Pengaruh Pemahaman Knowledge Sharing terhadap Prestasi Mahasiswa yang Melaksanakan Praktek Pengalaman Lapangan (Studi pada Mahasiswa STKIP Nasional Padang Pariaman)

menerapkan pemahaman knowladge sharing $(\mathrm{X})$ karena variabel tersebut mendukung untuk meningkatkan prestasi mahasiswa. 3) Bagi peneliti selanjutnya yang akan meneliti topik yang sama disarankan untuk menambah variabel dalam model penelitian serta menggunakan data terbaru agar hasil penelitian menjadi up to date.

\section{DAFTAR PUSTAKA}

Arikunto, Suharsimi. 2009. Dasar-dasar Evaluasi Pendidikan. Jakarta:Bumi Aksara

Anas, Sudijono 2012. Pengantar Evaluasi Pendidikan. Jakarta: Raja Grafindo Persada

Fasikhah, S. S. \& Fatimah S. 2013. Self-Regulated Learning (SRL) Dalam Meningkatkan Prestasi Akademik Pada Mahasiswa. Jurnal Psikologi. 01 (01), 2301- 8267

Ghozali, Imam. 2011. "Aplikasi Analisis Multivariate Dengan Program SPSS”. Semarang: Badan Penerbit Universitas Diponegoro.

Hamalik, Oemar. 2009. Kurikulum dan Pembelajaran. Jakarta. Bumi Aksara.

Hartaji, Damar A. 2012. Motivasi Berprestasi Pada Mahasiswa yang Berkuliah Dengan Jurusan Pilihan Orangtua. Fakultas Psikologi Universitas Gunadarma. (tidak diterbitkan)

Hilmi Aulawi, Govindaraju Rajesri, Suryadi Kadarsah, Sudirman Iman. 2009. Hubungan Knowladge Sharing Behavior dan Individual Innovation Capabality. Jurnal Teknik Industri, Vol. 11, No. 2, Desember 2009, pp. 174-187 ISSN 1411-2485

Lumbantobing, Paul. 2011. Manajemen Knowledge Sharing Berbasis Komunitas, Knowledge Management Society Indonesia. Bandung

Noviyanti, Mery. 2011. Jurnal. Pengaruh Motivasi dan Ketrampilan Berkomunikasi Terhadap Prestasi Belajar Mahasiswa pada Tutorial Online Berbasis Pendekatan Kontekstual pada Matakuliah Atatistika Pendidikan. Tangerang Selatan: FKIP-UT. Vol. 12 No. 2

Pramono, B. K., \& Susanty, A. I. 2015. The Influence Of Personal Factors, Organizational Factors, and Technological Factors In The Use Of CIM Toward Employees Knowledge Sharing In PT. Jalan Tol Lingkar Luar Jakarta (PT. JLJ).

Prasasti Pinkan Amita Tri, 2012. “Pengaruh Strategi Pembelajaran Active Knowledge Sharing Terhadap Keterampilan Proses Sains dan Hasil Belajar Ranah Kognitif dan Ranah Afektif Siswa Kelas X Semester Genap SMA Negeri 2 Karanganyar", Jurnal Pendidikan Biologi

Sanchez, F. J. P \& Roda, M. D. S. 2013. Relationship between selfconcept and academic achievement in prymary student. Electronic Journal of Research in Educational Psychology and Psychopedagogy, 1 (1), 95-120. ISSN: 1696-2095.

Sani Abdullah,. 2013. Inovasi Pembelajaran. Jakarta: Bumi Aksara

Sabrani Ahmad S. 2007. Strategi Belajar Mengajar Micro Teaching. Ciputat. Ciputat Press Group.

Sajeva, Svatlana. 2014. Encouraging Knowledge Sharing Amoung Employees: how Reward Maters. Procedia-Social and Behavior Science.Procedia-Social Vol.156. 130-134

Setiarso, Bambang. 2006. "Manajemen pengetahuan (knowledge management) dan proses penciptaan pengetahuan". Ilmukomputer.com

Sudaryono. 2012. Dasar-dasar Evaluasi Pembelajaran. Yogyakarta: Graha Ilmu.

Sukmadinata, N.S. 2011. Metode Penelitian Pendidikan. Bandung: Remaja Rosadakarya

Syah Muhibbin. 2010. Psikologi Pendidikan dengan pendekatan baru. Bandung:PT Remaja Rosdakarya

Wahyuni, Rista Ramadhan Tri dan Anang Kistyanto. 2013. Pengaruh Berbagi Pengetahuan Terhadap Kinerja Departemen Melalui Inovasi Jasa/Pelayanan. Jurnal Ilmu Manajemen. Vol.1, No.4, 2013: 1076-1088.

Triana,A., Utami, H.N., Ruhana,I. 2016. Pengaruh Komunikasi Organisasi Terhadap Knowledge Sharing dan Kinerja Karyawan. Jurnal Administrasi Bisnis Vol.35 No.2 